\title{
浸炭材の疲労き裂の伝ぱ特性・停留特性に及ぼす $\gamma$ 粒径の効果
}

\author{
越智 達朗*·久保田 学*・田中 洋一 *2 \\ Effect of Austenite Grain Size on the Fatigue Crack Growth and Arrest Behavior of Carburized Steel \\ Tatsuro OchI, Manabu KUBOTA and Yoichi TANAKA
}

Synopsis : The effect of austenite grain size on the fatigue crack growth and arrest behavior of carburized steel was studied. On the fatigue test of same stress amplitude, the fatigue crack initiation of fine austenite grain steels is delayed in comparison with coarse austenite grain steels, but the difference of crack initiation life between fine grain steels and coarse grain steels is very slight against $10^{7}$ cycles. The improvement of crack arrest property is dominant for increasing fatigue limit by refinement of austenite grain size. The critical stress intensity factor for crack arrest under fatigue tests at the stress amplitude of the each fatigue limit of carburized steels is calculated by considering the effect of compressive residual stress. As a result, it becomes clear that the finer the austenite grain size, the larger becomes the critical stress intensity factor for crack arrest, and crack arrest property is improved remarkably by the refinement of austenite grain size.

Key words : carburized steel; bending fatigue; crack initiation; crack arrest; austenite grain size; compressive residual stress; stress intensity factor.

\section{1. 緒言}

浸炭材は主として, 自動車, 建設機械などの㐘車あるい は各種シャフトとして用いられている。近年, 二酸化炭素 排出量削減の強い要請から, 自動車の燃費改善を狙いとし て, 自動車部品の軽量・コンパクト化が強く求められてお り, 浸炭材についても高強度化が重要な課題となってい $3^{1-5)}$ 。本研究では, 浸炭材の必要な強度特性として, 曲 げ疲労強度を取り上げた。

筆者らは，既報のに扎いて，浸炭材に打ける疲労き裂の 伝ぱ挙動を解析し, 浸炭材の疲労強度が疲労破壊のどのよ うな素過程で律速されているのかについて検討を行い，き 裂の発生寿命は非常に早く, 浸炭材の時間強度は主として 表層から約 $0.3 \mathrm{~mm}$ の領域までのき裂の伝ぱ挙動によって, 疲労限は表層から約 $0.2 \mathrm{~mm}$ の領域までのき裂の停留挙動 によって律速されることを明らかにしている。また，浸炭 材の $\gamma$ 粒径の細粒化により疲労強度が大幅に増加し, き裂 の発生特性も向上することを明らかにしている7)。細粒 $\gamma$ による疲労強度の向上には，き裂の発生特性に加えて，き 裂の伝ぱ特性, 停留特性が改善されている可能性がある。

そこで, 本研究では浸炭材の疲労き裂の伝ぱ挙動, 停留 挙動に及ぼす $\gamma$ 粒径の効果について調査した。

\section{2. 実験方法}

供試鋼として, SCM420相当材で, 浸炭後の $\gamma$ 粒径を変 化させるために, Al: $0 \sim 0.065 \%, \mathrm{Nb}: 0 \sim 0.050 \%, \mathrm{~N}: 0.006 \sim$ $0.013 \%$ の範囲で変化させた 4 種類の材料を用いた。供試鋼 の化学成分を Table 1 に示す。

各供試材とも，100 kg 真空溶解材であり，熱間鍛造によ り直径 $20 \mathrm{~mm} の 丸$ 棒に成形した後, $1200^{\circ} \mathrm{C} \times 1$ 時間加熱放冷の条件で熱間鍛造のシミュレートを，さらに $900^{\circ} \mathrm{C} \times 1$ 時間の条件で焼準処理を行った。丸棒から疲労試験片を削 り出し, Fig. 1に示す条件で浸炭熱処理を行った。有効硬

Table 1. Chemical composition of steels (mass\%).

\begin{tabular}{c|c|c|c|c|c|c|c|c|c|c}
\hline No. & $\mathrm{C}$ & $\mathrm{Si}$ & $\mathrm{Mn}$ & $\mathrm{P}$ & $\mathrm{S}$ & $\mathrm{Cr}$ & $\mathrm{Mo}$ & $\mathrm{Al}$ & $\mathrm{Nb}$ & $\mathrm{N}$ \\
\hline G1 & 0.20 & 0.31 & 0.76 & 0.002 & 0.021 & 0.97 & 0.18 & 0.002 & - & 0.006 \\
\hline G2 & 0.19 & 0.28 & 0.76 & 0.002 & 0.021 & 0.98 & 0.19 & 0.011 & 0.032 & 0.006 \\
\hline G3 & 0.19 & 0.28 & 0.75 & 0.002 & 0.020 & 0.96 & 0.18 & 0.021 & - & 0.006 \\
\hline G4 & 0.19 & 0.30 & 0.75 & 0.002 & 0.020 & 0.95 & 0.18 & 0.065 & 0.050 & 0.013 \\
\hline
\end{tabular}

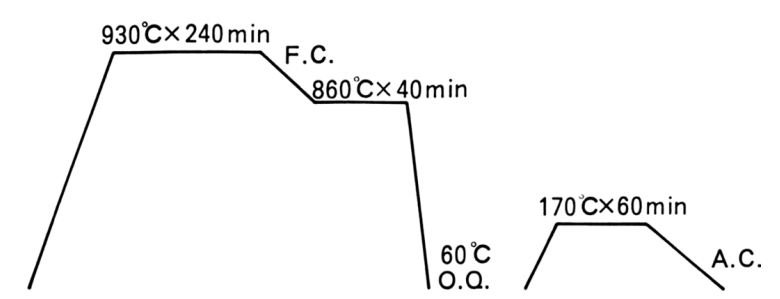

Fig. 1. Condition of carburizing.

平成 23年4月 11 日受付 平成23年7月 25 日受理 (Received on Apr. 11, 2011; Accepted on July 25, 2011)

* 新日本製鐵（株）室蘭技術研究部 (Muroran R\&D Lab., Nippon Steel Corporation, 12 Nakamachi Muroran 050-8550)

* 2 新日本製鐵（株）大分製鐵所 (Ooita Works, Nippon Steel Corporation) 
化層深さ $(\mathrm{HV}=550)$ は, 約 $0.95 \mathrm{~mm}$ である。

疲労強度は, 平行部直径 $8 \mathrm{~mm}$, 平行部長さ $50 \mathrm{~mm}$ の平 滑試験片を用いて，小野式回転曲げ疲労試験により評価し た。試験片平行部の表面は浸炭ままである。

また, 疲労き裂の伝ぱ挙動の解析, 停留き裂長さの調査 は, 次の方法によって行った。所定の応力振幅で所定の繰 返し数まで疲労試験を行った後, いったん疲労試験を中断 し, 応力振幅を $1400 \mathrm{MPa}$ まで増加させて再び応力を負荷 することにより短時間で疲労破断させた。この破断試験片 の破面を走査型電子顕微鏡により詳細に観察すると, 破壞 形態の違いによって, 最初の応力振幅で導入された疲労き 裂と応力振幅 $1400 \mathrm{MPa}$ で導入された疲労き裂の識別が可 能である。そこで, この最初の応力振幅で導入された疲労 き裂のなかで, 最長のき裂の長さを測定し, その応力振幅 一繰返し数に打けるき裂長さとして代表させた。種々の破 断繰返し数について，この方法を繰り返すことにより，そ の応力振幅における疲労き裂の伝ぱ曲線を求めた。また， 疲労限以下の応力振幅で $10^{7}$ 回疲労試験後, 未破断の試験 片で存在する停留き裂長さの調査も同様の方法で行った。

硬さは, 疲労試験片の直径 $8 \mathrm{~mm}$ の平行部の断面におい て,ビッカース硬さ計により測定した。

浸炭後の $\gamma$ 粒径は, 試験片表層の浸炭層について, JIS G 0551「鋼のオーステナイト結晶粒度試験方法」の切断法 に基づき, 11 結晶粒当たりの平均線分長」として求めた。

また, 残留応力は, $\mathrm{Cr}-K \alpha$ 線（浸透深さ：約 $12 \mu \mathrm{m}$ ）を 使用し, $30 \mathrm{kV}, 10 \mathrm{~A}$ の条件で, 疲労試験片の直径 $8 \mathrm{~mm}$ の 平行部で軸方向について測定した。表面から深さ方向への 残留応力分布は, 直径 $8 \mathrm{~mm}$ の平行部に执いて, 電解研磨一 残留応力の測定を逐次繰り返すことにより測定した。

残留オーステナイト量は, Mo- $K \alpha$ 線（浸透深さ：約 15 $\mu \mathrm{m}$ ) を使用し， $50 \mathrm{kV}, 150 \mathrm{~mA}$ の条件で, 疲労試験片の 直径 $8 \mathrm{~mm}$ の平行部の, 表面から深さ方向へ約 $80 \mu \mathrm{m}$ 電解 研磨した面で測定した。

\section{3. 曲げ疲労試験における応力拡大係数の計算方法}

本研究における $K$ 值の計算は以下の手法によった ${ }^{8)}$ 。き 裂がある有限試験片に対して，き裂から十分に離れた筒所 で分布応力が負荷された場合の $K$ 值は, 重ね合わせの原理 から，き裂が進展することにより開放された応力がき裂内 面に内圧として作用した場合の $K$ 值に等しくなり，後者の $K$ 值を計算することにより, 前者の $K$ 值を求めることがで きる9)。本研究では $K$ 值の算出に際して, 近似的に半無限 板の外側クラックとして取扱い，内面に集中荷重 $\sigma$ を受け る場合の $K$ 值の計算式である(1)式到を用い，分布応力に 対して，き裂が進展することにより開放された応力がき裂 内面に内压として作用すると考えて，(1)式を表面からき 裂先端まで数值積分することにより求めた。

$$
K=2 \sigma /\left(\pi a\left(1-b^{2} / a^{2}\right)\right)^{1 / 2} \times F(b / a)
$$

$F(b / a)$ : 形状係数であり, 文献10)の図より求めた。

$a$; き裂長さ $b$ : 集中荷重 $\sigma$ が付与される位置（表面 からの距離)

すなわち，外力による $K$ 值振幅： $\Delta K_{\text {applied }} / 2\left(=K_{\text {max }}\right) に つ$ いては, 曲げ応力の分布応力に対して, また残留応力によ

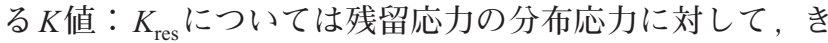
裂が進展することにより開放された分布応力がき裂内面に 内圧として作用すると考えて，(1)式を表面からき裂先端 まで数值積分することにより，それぞれ算出した。

\section{4. 実験結果および考察}

各浸炭材の回転曲げ疲労試験結果を Fig. 2に示す。図中 の鋼種番号の後の括弧内に $\gamma$ 粒径を示したが， G1 鋼で 140 $\mu \mathrm{m}, \mathrm{G} 2$ 鋼で $35 \mu \mathrm{m}, \mathrm{G} 3$ 鋼で $27 \mu \mathrm{m}, \mathrm{G} 4$ 鋼で $18 \mu \mathrm{m}$ と Al, $\mathrm{Nb} ， \mathrm{~N}$ 量を変化させることにより， $\gamma$ 粒径を $18 \sim 140 \mu \mathrm{m}$ の 範囲で4水準に変化させることができた。Fig. 2 から， $\gamma$ 粒 の細粒化によって, 疲労限, 時間強度ともに著しく向上す ることがわかる。各供試材の表層には，浸炭時に生成する 粒界酸化層が存在し，この粒界酸化層がいずれも疲労破壊 の起点となっている。各供試材の粒界酸化層深さ $D_{\mathrm{IO}}$ を， 硬化層硬さ（深さ $50 \mu \mathrm{m}$ で測定），残留オーステナイト量 （深さ $80 \mu \mathrm{m}$ で測定）と併せて Table 2に示す。

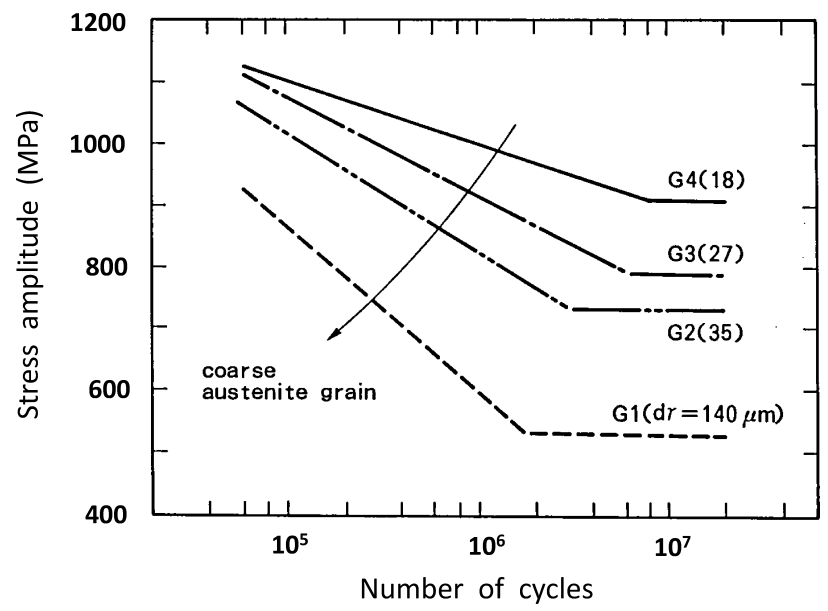

Fig. 2. Effect of austenite grain size on S-N curves of rotating bending fatigue test.

Table 2. Austenite grain size, case hardness, amount of retained austenite and intergranular oxidation depth of carburized steels.

\begin{tabular}{c|c|c|c|c}
\hline No. & G1 & G2 & G3 & G4 \\
\hline $\mathrm{d}_{\nu}(\mu \mathrm{m})$ & 140 & 35 & 27 & 18 \\
\hline Case hardness (HV 0.98N) & 729 & 729 & 715 & 739 \\
\hline Retained austenite $(\%)$ & 27.3 & 30.0 & 34.7 & 35.0 \\
\hline$D_{10}(\mu \mathrm{m})$ & 9 & 15 & 14 & 12 \\
\hline
\end{tabular}


ここで, 疲労限応力以下の種々の応力振幅で $10^{7}$ 回疲労 試験した試験片において，停留き裂が観察される。Fig. 3 に, 疲労限材および疲労限以下の種々の応力で $10^{7}$ 回繰り 返しを与えた材料について, 応力振幅と停留き裂長さの関 係を示す。例えば， $\mathrm{G} 1$ 鋼では，疲労限における停留き裂 長さは約 $0.4 \mathrm{~mm}$ であるが, 応力振幅を下げると, $400 \mathrm{MPa}$ では約 $0.3 \mathrm{~mm}, 300 \mathrm{MPa}$ では約 $0.1 \mathrm{~mm}$ と停留き裂長さは短 くなる。ここで, Fig. 3のプロットにおける傾きはき裂の 停留特性を表す指標に相当し，傾きが小さいほど，き裂の 停留特性は大きいと考えられる。Fig. 3 から，細粒 $\gamma$ 鋼ほ どプロットの傾きは小さくなっており，細粒 $\gamma$ 化によりき 裂の停留特性が増大している可能性が示唆される。

まず, $\gamma$ 粒径の異なる材料について, 同じ応力振幅で疲 労試験を行った場合のき裂の伝ぱ挙動, 停留挙動を調査し た。Fig. 4 は G3 鋼（ $\gamma$ 粒径 $27 \mu \mathrm{m} ）$ の疲労限応力 $770 \mathrm{MPa}$ において, G3 鋼と $\mathrm{G} 1$ 鋼（ $\gamma$ 粒径 $140 \mu \mathrm{m} ）$ の疲労き裂の伝 ぱ挙動を調べた結果である。き裂の発生寿命は, G1 鋼で 約 $10^{2}$ 回に対して，G3 鋼では $10^{4}$ 回と $\gamma$ 粒径を $140 \mu \mathrm{m}$ から $27 \mu \mathrm{m}$ に細粒化することによって約 2 オーダー伸びること がわかる。つまり，既報7)で示した $\gamma$ 粒の細粒化によるき 裂の発生特性の向上効果は，き裂が発生しうる応力振幅で みると発生寿命の遅延という形で現れることがわかる。と ころが, Fig. 4 は横軸を対数プロットしているが，これを

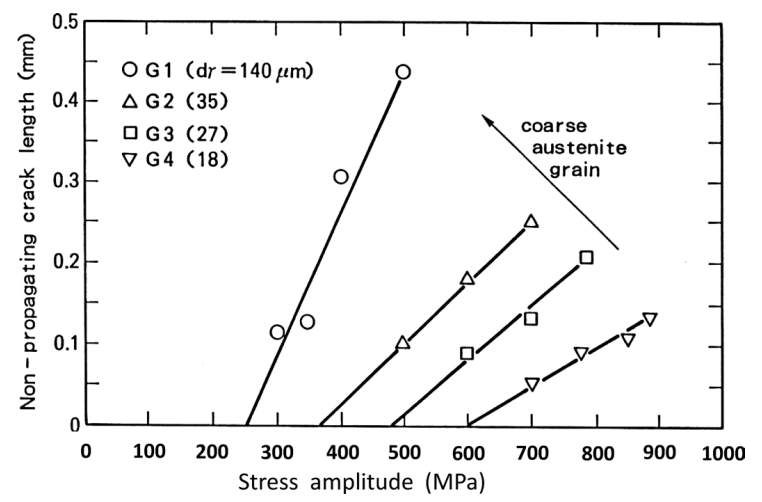

Fig. 3. Relationship between stress amplitude and nonpropagating crack length after fatigue test of $10^{7}$ cycles.

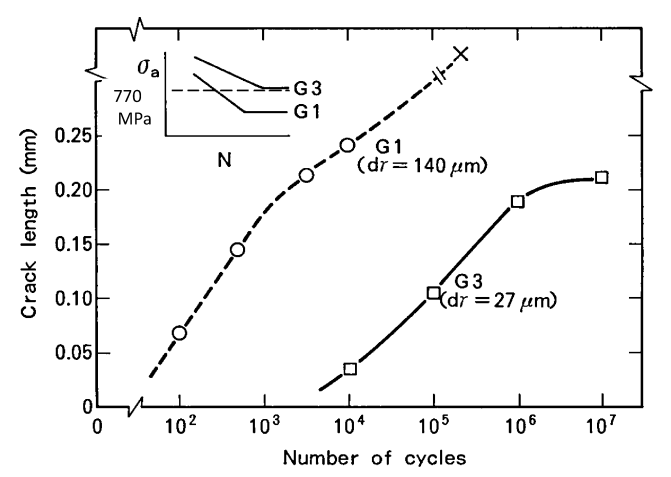

Fig. 4 Effect of austenite grain size on fatigue crack growth curves of rotating bending fatigue tests.
リニアでプロットし直すと Fig. 5のようになり，107回とい うオーダーでみると粗粒 $\gamma$ 鋼と細粒 $\gamma$ 鋼の発生寿命の差は 極めて小さいことがわかる。つまり， $\gamma$ 粒の細粒化によっ て発生寿命は遅延するものの，その絶対值自体の差は極め て小さく，応力振幅 $770 \mathrm{MPa}$ において， $\gamma$ 粒径を $140 \mu \mathrm{m}$ か ら $27 \mu \mathrm{m}$ に細粒化することによって疲労破壊を起こさなく なるのは，き裂の停留特性の向上が主たる原因であるとい うことができる。

ここで，浸炭材において，き裂の伝ぱ抵抗向上に対して 最も影響が大きいと考えられる圧縮残留応力は, 疲労過程 で増加する ${ }^{6}$ 。き裂の伝ぱ抵抗の向上に寄与する圧縮残留 応力分布は, き裂が伝ぱする時点での残留応力分布のため, き裂の発生特性が向上すれば，つまり，発生寿命が遅延す れば圧縮残留応力の増加を介してき裂の伝ぱ抵抗向上に寄 与する可能性があると考えられる。そこで，Fig. 4 におけ るき裂発生寿命，つまり $\mathrm{G} 1$ 鋼では $10^{2}$ 回応力繰返し負荷し た材料の， G3 鋼では $10^{4}$ 回応力繰り返し負荷した材料の残 留応力分布を調べた結果を Fig. 6 に示す。疲労試験前材の 圧縮残留応力は，粗粒 $\gamma$ 鋼のほうが圧縮側（マイナス側） に若干大きいが，き裂の発生寿命での圧縮残留応力は，発 生寿命の遅延する細粒 $\gamma$ 鋼のほうが逆に大きくなってい る。ここで, この残留応力分布を用いて, 疲労き裂が 0.21 mm（G3 鋼の停留き裂長さ）まで伝ぱしたときの残留応 力による $K$ 值： $K_{\mathrm{res}}$ は，3章に示した方法で計算すると， $\mathrm{G} 1$ 鋼で $K_{\mathrm{res}}=-9.5 \mathrm{MPa} \cdot \mathrm{m}^{1 / 2}, \mathrm{G} 3$ 鋼で $K_{\mathrm{res}}=-11.4 \mathrm{MPa} \cdot \mathrm{m}^{1 / 2}$ となる。つまり，0.21 mmのき裂がさらに伝ぱするか否か の状況で，き裂の伝ぱ抵抗増大に有効に寄与する圧縮残留 応力による $K$ 值は，粗粒 $\gamma$ 鋼 $\mathrm{G} 1$ 鋼に比較して細粒 $\gamma$ 鋼 $\mathrm{G} 3$ 鋼のほうが圧縮側に約 $20 \%$ 大きい。以上から，107回とい うオーダーでみると, 細粒 $\gamma$ 鋼と粗粒 $\gamma$ 鋼の発生寿命の差 の絶対值は小さいが，細粒 $\gamma$ 化によるき裂発生寿命の遅延 は, 疲労限の向上に対して全く効果を有していないわけで はなく，疲労過程での圧縮残留応力の増加を通じて，き裂 の伝ぱ抵抗の向上に寄与している可能性が考えられる。

次に, 各供試材の疲労限応力でのき裂の停留特性に及ほ す $\gamma$ 粒径の影響について調査した。 $\gamma$ 粒径の異なる各供試

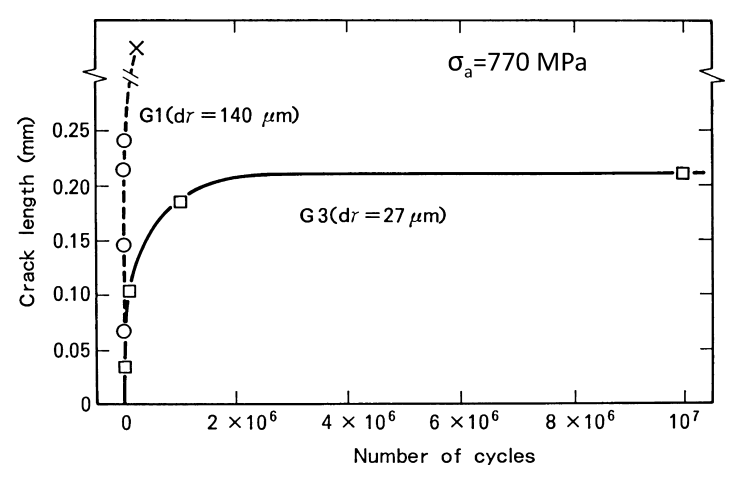

Fig. 5 Effect of austenite grain size on fatigue crack growth curves of rotating bending fatigue tests. 

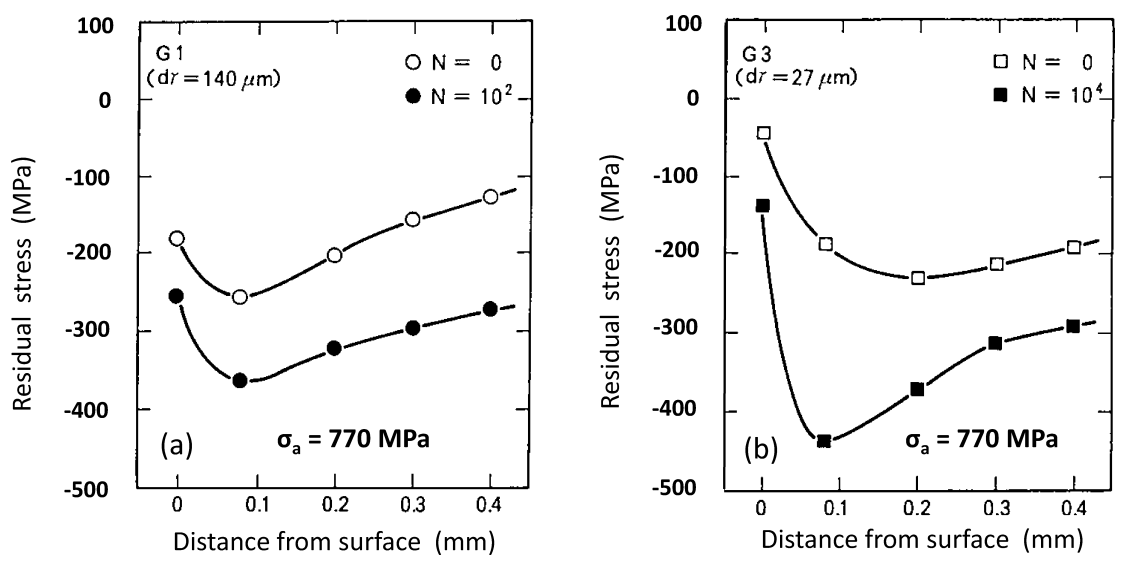

Fig. 6. Residual stress distribution at the cycles of crack initiation life on the process of fatigue tests of the stress amplitude of 770 MPa: (a) G1 and (b) G3.

材の疲労限材の停留き裂長さを疲労限と併せて Table 3 に 示す。 $\gamma$ 粒の細粒化によって, 疲労限は著しく向上するが, 疲労限応力での停留き裂長さは $\mathrm{G} 1$ 鋼で $0.44 \mathrm{~mm}, \mathrm{G} 2$ 鋼で $0.25 \mathrm{~mm}, \mathrm{G} 3$ 鋼で $0.21 \mathrm{~mm}, \mathrm{G} 4$ 鋼で $0.14 \mathrm{~mm}$ と細粒 $\gamma$ 鋼ほ ど短い。逆にいうと, 疲労限材の停留き裂長さは, 疲労限 の低い粗粒 $\gamma$ 鋼ほど長くなる。これらの疲労限応力と停留 き裂長さのデータを用いて, 各供試材の疲労限応力におい て, き裂が停留する条件について考察した。残留応力が存 在する材料の中を疲労き裂が伝ぱする場合，残留応力はき 裂に対する平均応力として作用し，平均応力効果によりき 裂開口応力拡大係数 $K_{\mathrm{op}}$ を変化させる ${ }^{9,11}$ 。 $K_{\mathrm{op}}$ に対する影 響因子として, 圧縮残留応力, 塑性変形など複数考えられ るが, 浸炭材では, 残留応力の影響が他の要因に比較して 大きいことが予想される。 $K_{\mathrm{op}}$ に対する影響因子として残 留応力の影響のみを考慮した応力拡大係数範囲を $\Delta K_{\text {effres }}$ と定義すると，次式で与えられる ${ }^{8)}$

$\Delta K_{\text {eff,res }}=\Delta K_{\text {applied }} / 2+K_{\text {res }}$

$\Delta K_{\text {applied }}$ : 外力による $K$ 值範囲

$K_{\mathrm{res}}$ : 残留応力による $K$ 值

疲労限においてき裂が停留するための限界 $K$ 值を $\Delta K_{\text {arrest }}$ とすると, (2)式を用いて疲労限応力でき裂が停留き裂長 さまで伝ぱしたときの $\Delta K_{\mathrm{eff}, \mathrm{res}}$ を計算することにより $\Delta K_{\mathrm{ar}-}$ rest を求めることができる。各鋼種について, 外力による $K$ 值範囲： $\Delta K_{\text {applied }} / 2$, 残留応力による $K$ 值： $K_{\text {res }}$ を 3 章に示 した方法で計算し，(2)式により疲労限においてき裂が停 留するための限界 $K$ 值： $\Delta K_{\text {arrest }}$ 求めた。その結果を Table 4 に示す。き裂が停留する外力による $K$ 值範囲 : $\Delta K_{\text {applied }} / 2$ は， $\gamma$ 粒径によらず $19.1 \sim 20.1 \mathrm{MPa} \cdot \mathrm{m}^{1 / 2}$ の值と なっている。細粒 $\gamma$ 鋼に比較して粗粒 $\gamma$ 鋼ほど痛労限は低 いが，疲労限材の停留き裂長さは，粗粒 $\gamma$ 鋼ほど長くなる ために, 疲労限応力と停留き裂長さから計算される外力に よる $K$ 值範囲： $\Delta K_{\text {applied }} / 2$ は, 結果的に $\gamma$ 粒径の違いで大き な差がなくなっているものと考えられる。一方, 残留応力
Table 3. Effect of austenite grain size on fatigue limit and non-propagating crack length of rotating bending fatigue test of carburized steels.

\begin{tabular}{c|c|c|c|c}
\hline No. & $\mathrm{G} 1$ & $\mathrm{G} 2$ & $\mathrm{G} 3$ & $\mathrm{G} 4$ \\
\hline $\mathrm{d}_{\gamma}(\mu \mathrm{m})$ & 140 & 35 & 27 & 18 \\
\hline$\sigma_{\mathrm{w}}(\mathrm{MPa})$ & 530 & 730 & 790 & 910 \\
\hline $\begin{array}{c}\text { Non-propagating } \\
\text { crack length (mm) }\end{array}$ & 0.44 & 0.25 & 0.21 & 0.14 \\
\hline
\end{tabular}

Table 4. Effect of austenite grain size on $\Delta K_{\text {applied }} / 2, K_{\text {res }}$ and $\Delta K_{\text {arrest }}$ under fatigue tests at the stress amplitude of the each fatigue limit of carburized steels.

\begin{tabular}{c|c|c|c|c}
\hline No. & $\mathrm{G} 1$ & $\mathrm{G} 2$ & $\mathrm{G} 3$ & $\mathrm{G} 4$ \\
\hline $\mathrm{d}_{\nu}(\mu \mathrm{m})$ & 140 & 35 & 27 & 18 \\
\hline$\Delta \mathrm{K}_{\text {applied }} / 2\left(\mathrm{MPa} \cdot \mathrm{m}^{1 / 2}\right)$ & 19.7 & 20.5 & 20.4 & 19.1 \\
\hline $\mathrm{K}_{\text {res }}\left(\mathrm{MPa} \cdot \mathrm{m}^{1 / 2}\right)$ & -13.7 & -12.0 & -11.4 & -9.6 \\
\hline$\Delta \mathrm{K}_{\text {arrest }}\left(\mathrm{MPa} \cdot \mathrm{m}^{1 / 2}\right)$ & 6.0 & 8.5 & 9.0 & 9.5 \\
\hline
\end{tabular}

による $K$ 值： $K_{\mathrm{res}}$ は, 細粒 $\gamma$ 鋼に比較して, 粗粒 $\gamma$ 鋼ほど 圧縮側（マイナス側）に大きな值となる。上記において， $\gamma$ 粒径の異なる材料について同一応力振幅でき裂が同じ長 さまで伝ぱしたときの残留応力による $K$ 值 : $K_{\mathrm{res}}$ は, 細粒 $\gamma$ 鋼のほうが粗粒 $\gamma$ 鋼に比較して圧縮側（マイナス側）に 大きくなることを明らかにしたが，おのおのの疲労限応力 でき裂が停留するのに寄与する残留応力による $K$ 值 : $K_{\mathrm{res}}$ に及ぼす $\gamma$ 粒径の影響は, 逆に粗粒 $\gamma$ 鋼のほうが細粒 $\gamma$ 鋼 に比較して圧縮側（マイナス側）に大きくなる結果になっ ている。これは, 残留応力による $K$ 值： $K_{\mathrm{res}}$ は, き裂進展 に伴い開放される圧縮残留応力がき裂内面に内圧として作 用するとして計算されるために, 停留き裂長さの長い粗粒 $\gamma$ 鋼ほど, き裂内面に内圧として作用する圧縮応力が広範 囲になるためである。以上の結果，外力による $K$ 值範囲と 残留応力による $K$ 值の和として求められる疲労限において き裂が停留するための限界 $K$ 值： $\Delta K_{\text {arrest }}$ は, 細粒 $\gamma$ 化する ほど大きな值となる。例えば, $\gamma$ 粒径を $140 \mu \mathrm{m}$ から $18 \mu \mathrm{m}$ 


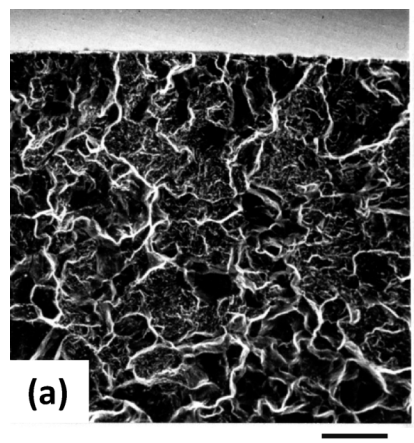

$50 \mu \mathrm{m}$

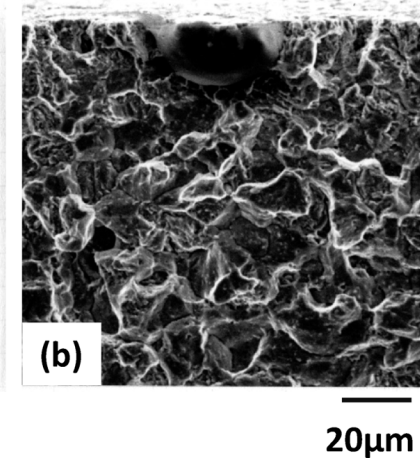

$20 \mu \mathrm{m}$
Fig. 7. SEM fractographs showing crack initiation sites of fatigue fractured specimens: (a) G2 and (b) G4.

へ細粒 $\gamma$ 化することにより， $\Delta K_{\text {arrest }}$ は $6.0 \mathrm{MPa} \cdot \mathrm{m}^{1 / 2}$ から 9.5 $\mathrm{MPa} \cdot \mathrm{m}^{1 / 2}$ へと約 1.6 倍にも向上する。疲労限に打いてき裂 が停留するための限界 $K$ 值： $\Delta K_{\text {arrest }}$ が細粒 $\gamma$ 鋼ほど大きく なることは， $\gamma$ 粒径の微細化それ自体が，疲労き裂の停留 特性向上に顕著な効果を有していることを意味している。

Fig. 7 に2 鋼打よびG4鋼の応力振幅 $1000 \mathrm{MPa}$ において 疲労破断した試験片の疲労破面写真を示す。ともに旧オー ステナイト粒界割れが混入した破壊形態を呈しており，粒 界割机破面率は細粒 $\gamma$ 鋼ほど高い。疲労破壊に打ける粒界 破面の出現に関しては,「疲労き裂先端の繰り返し塑性域 内部での粒界のすべりに対する拘束がもたらす結果とし て, 疲労き裂先端の繰返し塑性域寸法 $R_{\mathrm{p}}$ と結晶粒径 $D$ の 比 $R_{\mathrm{p}} / D$ が $0.2 \sim 0.8$ の範囲で, 粒界割れ破面率が高くなる」 と言われている ${ }^{12)}$ 。本研究に打ける供試材は，硬化層硬さ が HV700 以上と硬さが顕著に硬いため, 疲労き裂先端の 繰返し塑性域寸法 $R_{\mathrm{p}}$ が小さく, 繰返し塑性域寸法 $R_{\mathrm{p}}$ と結 晶粒径 $D$ の比 $R_{\mathrm{p}} / D$ はいずれの鋼種も 0.2 未満の值となる。 その結果，粗粒 $\gamma$ 鋼に比較して, 細粒 $\gamma$ 鋼ほど相対的に $R_{\mathrm{p}} / D$ が大きく, 0.2 に近い值となるため, 細粒 $\gamma$ 鋼ほど粒 界割机破面率が高くなったものと推察される。いずれにし ても，粒界割れ破面率が多いほどき裂の伝ぱ抵抗は小さい と考えられるで, 細粒 $\gamma$ にるき裂の停留特性（伝ば抵抗） の向上効果は，破壊形態では説明できない。逆にいうと， 細粒 $\gamma$ 化で粒界割机破面率が高くなるマイナスの影響以上 に, 細粒 $\gamma$ 化がき裂の停留特性の向上に対して顕著な効果
を有しているということができる。

\section{5. 結言}

粒界酸化層を有した浸炭材に打ける疲労き裂の伝ぱ挙 動, 停留挙動に及ぼす $\gamma$ 粒径の効果について調査した結果, 次の点が明らかとなった。

(1) 疲労限は細粒 $\gamma$ 鋼ほど向上する。細粒 $\gamma$ 鋼で疲労 限となり，粗粒 $\gamma$ 鋼で破断する同一の応力振幅で比較した 場合， $\gamma$ 粒の細粒化によって疲労き裂の発生寿命は遅延す る。ただし，107回というオーダーでみると，発生寿命の 差の絶対值は小さく, 同一の応力振幅で比較した場合, 細 粒 $\gamma$ 化により疲労破壞を起こさなくなるのは，き裂の停留 特性向上による。

(2) $\gamma$ 粒径の異なる各供試材の疲労限応力での停留き 裂長さは，疲労限応力の高い細粒 $\gamma$ 鋼ほど短く，疲労限応 力の低い粗粒 $\gamma$ 鋼ほど長い。各供試材の疲労限応力におい て，圧縮残留応力の影響を考虑してき裂が停留する限界応 力拡大係数を計算した結果，この限界応力拡大係数は $\gamma$ 粒 径の影響を受け， $\gamma$ 粒径を $140 \mu \mathrm{m}$ から $18 \mu \mathrm{m}$ 一微細化する ことにより，約 1.6 倍にも増加する。以上から， $\gamma$ 粒径の 微細化それ自体が，疲労き裂の停留特性向上に対して顕著 な効果を有していることが明らかである。

\section{文献}

1 ) M.Hirai, M.Uno and F.Nakasato: Sumitomo Met., 41 (1989), No. 4, 27

2 ) N.Murai, K.Aihara, S.Kanbara, T.Tsumura and K.Nisida: Sumitomo Met., 45 (1993), No. 4, 11.

3 ) H.Kanisawa, T.Ochi and Y.Koyasu: Nippon Steel Tech. Rep., 64 (1995), 50.

4 ) Y.Kurokawa, Y.Kamata, K.Nishida and N.Murai: Sumitomo Met., 48 (1996), No. 4, 204.

5 ) M.Nakamura, H.Takeshita, K.Akiba, T.Hasegawa and Y.Matsushima: Tetsu-to-Hagané, 72 (1986), S527.

6 ) T.Ochi, S.Kozawa and M.Kubota: Tetsu-to-Hagané, 97 (2011), 486

$7)$ T.Ochi, Y.Tanaka and T.Takahashi: Tetsu-to-Hagané, 73 (1987), S1301.

8 ) T.Ochi, M.Kubota and Y.Tanaka: Netsu Syori (J. Jpn. Soc. Heat Treat.), (2011), 投稿中.

9 ）小林英男：破壊力学, 共立出版, (2004), 73 .

10) 岡村弘之：線形破壊力学入門，培風館, (1978), 216 .

11) 小林英男：破壊力学, 共立出版, (2004), 134.

12）小寺沢良一：フラクトグラフィとその応用，日刊工業新聞社, (1981), 127. 